\title{
Travel Medicine in the Gulf Cooperation Council Countries
}

\author{
Ayman Al-Dahshan ${ }^{1}$, Mohamad Abdul Halim Chehab $^{1 *}$, Mohamed Bala ${ }^{1}$ \\ ${ }^{1}$ Community Medicine Residency Program, Hamad Medical Corporation, Doha, Qatar
}

Corresponding Author: Mohamad Abdul Halim Chehab, Resident Physician, Community Medicine Residency Program, Hamad Medical Corporation, Doha, Qatar. Tel: +974-50448524, Email: mohamadchehab1989@gmail.com

Received November 8, 2017; Accepted November 28, 2017; Online Published January 29, 2018

Citation: Al-Dahshan A, Chehab MAH, Bala M. Travel medicine in the Gulf Cooperation Council countries. Int J Travel Med Glob Health 2018;6(1):35. doi:10.15171/ijtmgh.2018.08.

\section{Dear Editor,}

Depending on the characteristics of both the traveler as well as the journey, travel can pose various health risks. Hence, travel medicine, which is concerned with the promotion of health and prevention of disease among international travelers while mitigating any impact on the health of the local population, is of great importance. ${ }^{1}$ This specialty has become complex because of the volatile landscape of global infectious diseases as well as a rise in the number of travelers with chronic health conditions. ${ }^{2}$ Thus, any physician preparing a traveler must perform a risk assessment of the planned journey, provide education about disease and dangerous events' prevention, advise the traveler on health maintenance, administer appropriate vaccines, and offer post-travel care. ${ }^{3}$

Tourism has emerged as a vital economic sector for the Gulf Cooperation Council (GCC) countries as a means for diversifying economies away from the oil industry. Despite the fact that their populations represent only $20 \%$ of the total population of the region, the GCC countries - Saudi Arabia, Bahrain, United Arab Emirates, Kuwait, Oman, and Qatar are key source markets for outbound travel from the Middle East, contributing to more than half $(60 \%)$ of the travel volume and three-quarters (75\%) of travel spending. ${ }^{4}$ In 2012, the most significant source markets were Saudi Arabia (47\%), United Arab Emirates (31\%), and Kuwait (22\%); together, these countries accounted for a total volume of 11.5 million arrivals to foreign destinations. ${ }^{5}$ Popular destinations outside the Middle East region include countries in Europe, Asia, and the Pacific, ${ }^{4}$ and have contributed to an increased outbound tourism flow from GCC countries in recent years.

Another vital aspect of travel is the annual pilgrimage (Hajj) for Muslims to Mecca, Saudi Arabia (KSA). Every year, the KSA hosts more than four million people from 160 countries worldwide for the Umra and Hajj season, making the Hajj pilgrimage one of the largest mass gatherings in the twenty-first century. Consequently, such gathering poses several potential risks, including physical or heat exhaustion, crowded accommodations, infectious disease propagation, and human stampedes, necessitating the need for targeted preventive measures. ${ }^{6}$

\section{Authors' Contributions}

All authors contributed equally to the conception and implementation of the work.

\section{Conflict of Interest Disclosures}

The authors have no conflicts of interest to declare.

Ethical Approval

Not applicable.

\section{Funding/Support}

None.

\section{References}

1. Committee to Advise on Tropical Medicine and Travel (CATMAT). An Advisory Committee Statement (ACS): Guidelines for The Practice of Travel Medicine. Ottawa: Public Health Agency of Canada; 2009. https://www.canada.ca/content/dam/phac-aspc/ migration/phac-aspc/publicat/ccdr-rmtc/09pdf/acs-dcc-08.pdf.

2. Zuckerman JN. Recent developments: Travel medicine. BMJ. 2002;325(7358):260-264. doi:10.1136/bmj.325.7358.260.

3. Kozarsky PE, Keystone JS. Body of knowledge for the practice of travel medicine. J Travel Med. 2002;9(2):112-115. doi:10.2310/7060.2002.21983.

4. The Middle East Outbound Travel Market with Special Insight into the Image of Europe as a Destination. Madrid: World Tourism Organization European Travel Commission; 2012.

5. Incoming-Tourism Germany Facts and Figures 2014. Frankfurt: German National Tourist Board (GNTB); 2015. https://www. germany.travel/media/pdf/dzt_marktforschung/GNTB_IncomingTourism-Germany-2015.pdf.

6. Manoochehry S, Rasouli HR. Recurrent human tragedy during Hajj. Int J Travel Med Glob Health. 2017;5(1):36-37. doi:10.15171/ ijtmgh.2017.07.

Copyright $(\subset 2018$ The Author(s). This is an open-access article distributed under the terms of the Creative Commons Attribution License (http:// creativecommons.org/licenses/by/4.0), which permits unrestricted use, distribution, and reproduction in any medium, provided the original work is properly cited. 